\author{
Інна Макаренко, Олена Кравченко, Наталія Овчарова, \\ Наталія Земляк, Сергій Макаренко
}

Сумський державний університет

Україна

\title{
СТАНДАРТИЗАЦІЯ АУДИТУ ЗВІТНОСТІ ЗІ СТАЛОГО РОЗВИТКУ КОМПАНІЙ
}

Метою статті $\epsilon$ обтрунтування доцільності використання стандартів, щзо регулюють порядок проведення аудиту звітності зі сталого розвитку, для упорядкування процесу верифікаиї̈ такої звітності в інтересах стейкхолдерів.

Методологія / методика / підхід. Методологічною основою дослідження виступають компаративний $і$ контент-аналіз міжнародно визнаних стандартів аудиту звітності зі сталого розвитку, зокрема Стандарту із надання впевненості AA1000 (AA1000AS, AccountAbility) та Міжнародного стандарту з надання впевненості МСЗНВ 3000 Ради з надання впевненості (International Standard on Assurance Engagements (ISAE 3000) «Завдання з надання впевненості, щуо не є аудитом, чи оглядом історичної фінансової інформації» Ради з надання впевненості. Застосування изи аналітичних інструментів дозволило виділити переваги та обмеження кожного з названих стандартів.

Результати. Установлено, що забезпечення незалежного аудиторського підтвердження звітності зі сталого розвитку характеризується зростаючим трендом серед найбільших світових компаній. Аудит є однією з умов забезпечення довіри до звітності зі сталого розвитку для стейкхолдерів, відповідно стандартизація аудиту звітності зі сталого розвитку виступає запорукою якості його проведення та надійності отриманих аудитором висновків. Проведено аналіз обсягів подання верифікованої звітності зі сталого розвитку та компаративний аналіз двох основних стандартів у сфері ї̈ аудиту за основними критеріями, щзо охоплюють їх статус, мету, верифікаторів, процеси, вимоги, обсяги та принщипи проведення, оформлення результатів та особливості публікації думки аудитора.

Орихінальність / наукова новизна. Обгрунтовано важливість $i$ доцільність застосування міжнародно визнаних стандартів AA1000 та ISAE 3000 як бенчмарків для стандартизації звітності зі сталого розвитку на основі визначених ӥхніх переваг та недоліків. Порівняльна характеристика ци оцінка частоти практичного застосування вказаних стандартів аудиту звітності зі сталого розвитку дістала дальшого розвитку.

Практична цінність / значущість. 3 урахуванням вигід та обмежень проаналізованих стандартів на регуляторному рівні, зокрема $і$ в Украйні, можуть бути розроблені національні підходи щцодо стандартизації аудиту звітності зі сталого розвитку. На рівні окремих компаній, зокрема великих аграрних холдингів, зазначені стандарти можуть використовуватися паралельно в комунікативному полі їхньої взаємодї зі стейкхолдерами залежно від категорій зазначених сторін.

Ключові слова: аудит, надання впевненості, звітність зі сталого розвитку, стейкхолдери, верифікація. 


\section{STANDARDIZATION OF COMPANIES' SUSTAINABILITY REPORTING AUDIT}

Purpose. The purpose of the article is to justify the use of sustainability reporting assurance standards to streamline the process of verification of such reporting in the interests of stakeholders.

Methodology / approach. The methodological basis of the study is a comparative and content analysis of internationally recognized standards for the audit of sustainability reporting, including the AA1000 (AA1000AS, AccountAbility) and the International Standard on Assurance Engagements (International Standard on ISAE 3000) «Non-Audit Assurance or Review of Historical Financial Information» IBAA. Use of these analytical tools highlighted the benefits and limitations of these standards.

Results. Authors defined that the provision of independent audit confirmation of sustainability reporting is characterized by a growing trend among the world's largest companies. Assurance is one of the conditions for ensuring confidence in sustainability reporting for stakeholders, and accordingly, standardization of audit is a guarantee of the quality of its conduct and the reliability of the auditor's conclusions. The analysis of volumes of verified sustainability reporting submission and comparative analysis of the two primary standards in the field of its audit by the main criteria was conducted. These criteria cover standards status, purpose, verifiers, processes, requirements, volumes, and principles of conduct, results in preparation and features of publication of the auditor's opinion.

Originality / scientific novelty. The importance and feasibility of applying the internationally recognized standards AA1000 and ISAE 3000 as benchmarks for standardizing sustainability reporting based on their identified advantages and disadvantages are substantiated. A comparative description and assessment of the frequency of practical application of these standards for auditing reporting on sustainable development was further developed.

Practical value / implications. Taking into account the benefits and limitations of the analyzed standards at the regulatory level, in particular in Ukraine, national approaches to standardizing the audit of sustainability reporting can be developed. At the level of individual companies, in particular large agricultural holdings, these standards can be used in parallel in the communication field of their interaction with stakeholders, depending on the categories of those stakeholders.

Key words: audit, assurance, sustainability reporting, stakeholders, verification.

Постановка проблеми. Інформаційні запити влади, суспільства чи власників завжди були незмінною причиною розвитку аудиту. Практика соціальної відповідальності бізнесу нині є новим об’єктом суспільного інтересу, що зумовлює посилення вимог щодо підзвітності та забезпечення прозорості діяльності компаній, оприлюднення нефінансових звітів (звітності зі сталого розвитку - ЗСР). Також зацікавлені сторони віддають перевагу перевіреній інформації через випадки банкрутства економічних гігантів в Італії, Японії, США та в інших країнах світу, які збільшувалися через опублікування 
недостовірної інформації. У випадку ЗСР забезпечення достовірності екологічної та соціальної інформації з урахуванням значної різноманітності індикаторів, у яких вона розкривається, набуває особливого значення. Тому аудит ЗСР $є$ однією $з$ умов забезпечення довіри до такої інформації зацікавлених сторін - стейкхолдерів, а також конкурентоспроможності компаній та їхньої інвестиційної привабливості. Своєю чергою, стандартизація процедур і підходів до здійснення аудиту ЗСР виступає запорукою якості його проведення та надійності отриманих аудитором висновків.

Аналіз останніх досліджень і публікацій. Дослідженню теоретичних i методологічних аспектів аудиту ЗСР приділяли увагу Н. Голубєва [1], O. Баришнікова [2], О. Мазурик [3], S. Waddock, N. Smith [4], R. Gray [5], А. Каптєрєв [6], В. Карагод [7], P. Kok, T. van der Wiele, R. McKenna, A. Brown [8], R. Morimoto, J. Ash, C. Hope [9], O. Boiral, I. Heras-Saizarbitoria, M. Brotherton [10], H. Al- Shaer, M. Zaman [11; 12], G. Michelon, D. Patten, A. Romi [13], I. Кауа [14], T. Васильєва, С. Лєонов, I. Макаренко, Н. Сірковська [15], а також інші вітчизняні та зарубіжні науковці. Разом із тим, значної уваги в аналізованих працях не приділено вивченню методологічних основ аудиту ЗСР, напрацюванню єдиних підходів до його здійснення для забезпечення зіставності й надійності отриманих аудиторських висновків щодо ЗСР.

Мета статті $є$ обгрунтування доцільності використання стандартів, що регулюють порядок проведення аудиту звітності зі сталого розвитку, для упорядкування процесу верифікації такої звітності в інтересах стейкхолдерів.

Виклад основного матеріалу дослідження. Забезпечення незалежного аудиторського підтвердження ЗСР характеризується зростаючим трендом серед найбільших світових компаній. Наявність такого тренду підтверджуємо, спираючись на авторитетну у світі базу ЗСР Corporateregister, яка містить 119875 подібних звітів станом на 01.06.2020 р. (рис. 1).

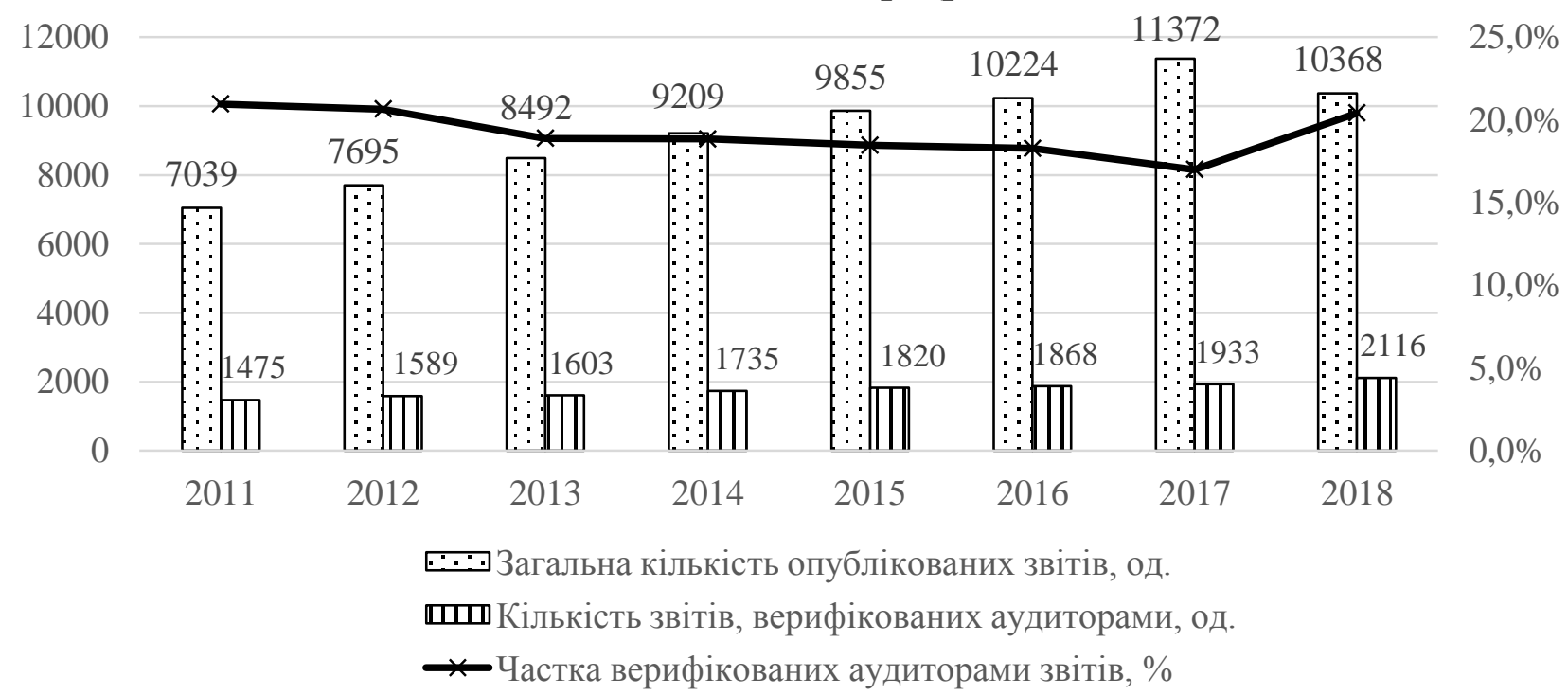

Рис. 1. Динаміка звітності зі сталого розвитку, що верифікусться аудиторами, у 2011-2018 pp. (за даними Corporateregister) Джерело: побудовано авторами на основі [16]. 
Як свідчать дані рис. 1, подання верифікованої за стандартами аудиту ЗСР має зростаючий тренд. При цьому частка таких звітів коливається від $17 \%$ до $21 \%$ упродовж 2011-2018 pp.

Більшою деталізацією та відповідно більшою часткою верифікованих ЗСР характеризуються дані періодичного дослідження KPMG. Так, на початку 2018 р. верифікація ЗСР аудиторами притаманна понад двом третинам звітів 250 найбільших світових корпорацій і близько $40 \%$ звітів 100 найбільших компаній із кожної з досліджуваних 49 країн світу (рис. 2).

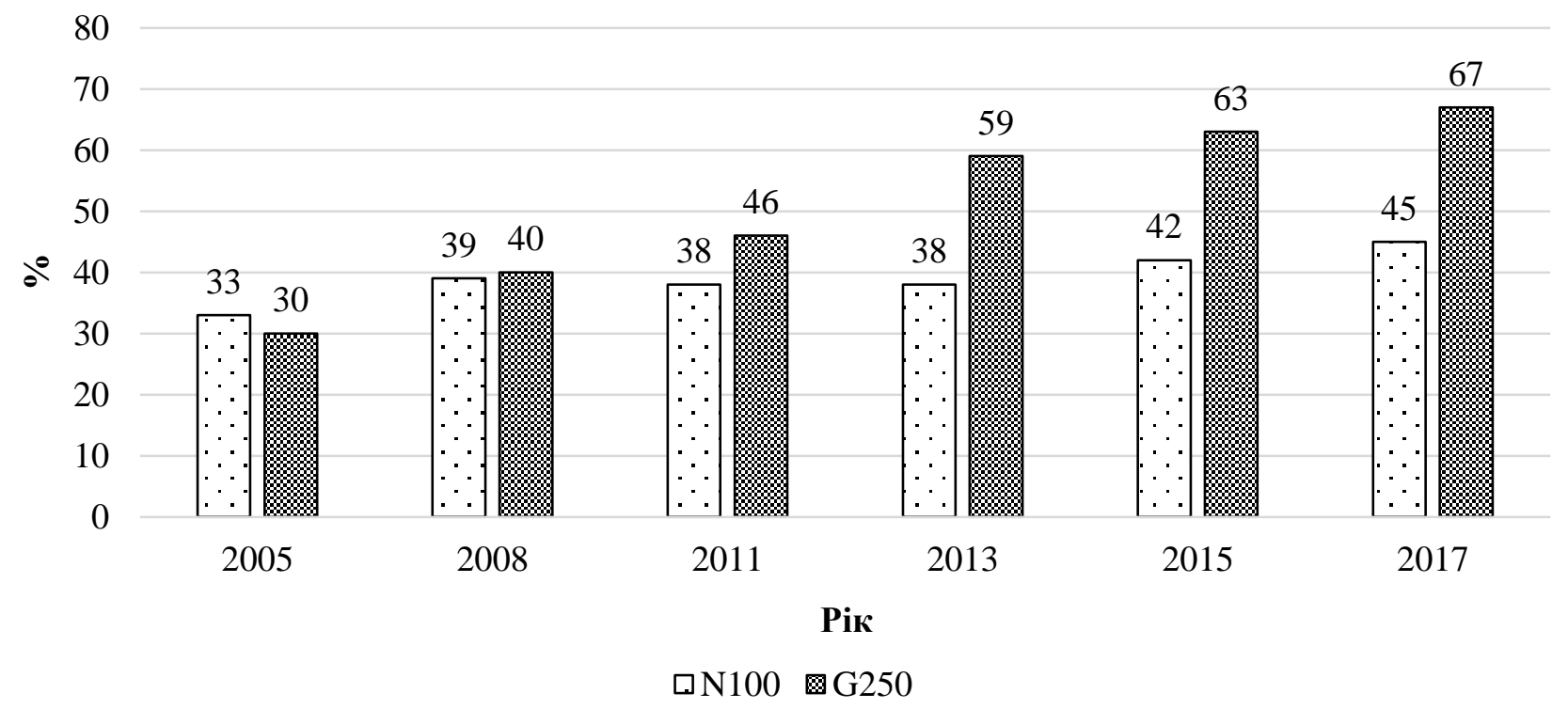

\section{Рис. 2. Частка ЗСР, що верифікуються аудиторами серед найбілыших} компаній світу у 2005-2017 pp. (за даними КPMG)

Джерело: розроблено авторами на основі [17].

Відмінності в обсягах та частках ЗСР, верифікованих аудиторами за стандартами аудиту, за даними Corporateregister.com та KPMG [16; 17], на нашу думку, пов'язані зі специфікою формування вибірки компаній і проведення досліджень KPMG. До звітів цієї компаній щодо поширення ЗСР та іiі верифікації потрапляють дані за найбільшими, топовими компаніями як окремо взятої країни, так і загалом у світі. Здебільшого саме ці компанії мають розвинену практику корпоративної соціальної відповідальності, регулярно публікують ЗСР та звертаються до найбільших аудиторських компаній світу щодо іiі підтвердження. До бази Corporateregister.com входять компанії, що звітують за показниками сталого розвитку незалежно від їх розмірів, тому реальна частка верифікованих за стандартами аудиту ЗСР усіх компаній у світі, на нашу думку, становить п'яту частину від їхнього загального обсягу.

У цілому ж подання в інтересах стейкхолдерів ЗСР, що має незалежне підтвердження відповідно до прийнятих стандартів аудиту, характеризується постійним зростанням обсягів.

Однією 3 причин такого зростання можна назвати законодавче упорядкування процесу верифікації ЗСР, що набуває в окремих країнах нормативного закріплення. Тобто ще одним трендом у верифікації ЗСР $\epsilon$ 


\section{Agricultural and Resource Economics}

www.are-journal.com

стандартизація цього процесу. Так, специфічні документи щодо врегулювання порядку аудиту ЗСР опубліковані у Франції (Decree 2012-557 on obligations regarding transparency on social and environmental disclosure by companies, 2012), Швеції (Guidelines for external reporting by state-owned companies, 2007), ПАР (Corporate Governance Code King III, 2010), Тайвані (Corporation Rules Governing the Preparation and Filing of Corporate Social Responsibility Reports by TWSE Listed Companies, 2015).

На наднаціональному рівні серед найбільш поширених стандартів аудиту ЗСР слід назвати Стандарт із надання впевненості AA1000 (AA1000AS, AccountAbility) та Міжнародний стандарт з надання впевненості МСЗНВ 3000 Ради 3 міжнародних стандартів аудиту та надання впевненості (International Standard on Assurance Engagements (ISAE 3000) «Завдання 3 надання впевненості, що не є аудитом, чи оглядом історичної фінансової інформації». Разом із тим, підходи до аудиту ЗСР, закладені в цих стандартах, відрізняються та потребують зіставлення. Однак, у порівнянні з названими національними чи галузевими підходами вимоги AA1000 та ISAE 3000 є більш загальними й універсальними. Саме вони можуть бути використані для напрацювання взірцевих підходів до стандартизації аудиту ЗСР через їх уніфікований характер.

Так, ISAE 3000 є міжнародним атестаційним стандартом, який дозволяє організаціям, що здійснюють міжнародну діяльність, отримувати звіт відповідно до визнаного міжнародного стандарту впевненості, для точності та достовірності нефінансової інформації. Зазначений міжнародний стандарт 3 надання впевненості випускається Міжнародною федерацією бухгалтерів та складається 3 настанов щодо етичної поведінки, управління якістю та виконання завдань ISAE 3000. Як правило, ISAE 3000 застосовується для аудиту внутрішньої діяльності компанії, тобто аналізується питання дотримання законодавства в економічній, екологічній i соціальній сферах, a також сталість розвитку організації та подальші перспективи [18; 19].

Відповідно до ISAE 3000, аудитор може формувати два типи звітів. Звіт першого типу забезпечує впевненість щодо придатності конструкції та існування засобів контролю, а звіт другого типу забезпечує впевненість у відповідності конструкції, існування та експлуатаційній ефективності.

На противагу ISAE 3000, є стандарт верифікації AA1000 AS, який слугує для оцінки та посилення достовірності та якості соціальної, економічної та екологічної звітності організацій. Він призначений насамперед для використання аудиторськими компаніями, які забезпечують звітами організації або постачальників послуг, але також можуть бути використані для керівництва будь-якою організацією під час побудови іiі процесів, систем і можливостей підзвітності.

Важливою особливістю AS1000 AS є залучення зацікавлених сторін, в рамках організацій це використовується як засіб для підвищення загальної ефективності за допомогою інновацій і навчання [20; 21]. 


\section{Agricultural and Resource Economics \\ www.are-journal.com}

AA1000 AS побудований на двох переконаннях. По-перше, такі процеси підзвітності повинні бути розроблені для визначення, розуміння та відповіді на питання, характерні для різних організацій, секторів, зацікавлених сторін і стратегій. По-друге, надійні, якісні процеси залучення зацікавлених сторін можуть потужно інформувати внутрішнє прийняття рішень і давати можливість навчанню та впровадження інноваційності, і таким чином, ефективно впливати на результативність. Більш детальний аналіз двох стандартів, що регулюють питання аудиту звітності зі сталого розвитку, відображено в табл. 1.

Таблиия 1

Порівняльна характеристика стандартів аудиту 3СР

\begin{tabular}{|c|c|c|}
\hline $\begin{array}{c}\text { Критерій } \\
\text { порівняння }\end{array}$ & ISAE 3000 & AA1000AS \\
\hline $\begin{array}{l}\text { Відповідальний } \\
\text { орган }\end{array}$ & $\begin{array}{l}\text { Рада } 3 \text { міжнародних стандартів } \\
\text { аудиту та надання впевненості }\end{array}$ & AccountAbility \\
\hline Статус & Прийнятий у грудні 2003 року & Вийшов у березні 2003 року \\
\hline Обов'язковість & Так & $\mathrm{Hi}$ \\
\hline Мета & $\begin{array}{l}\text { Підтвердження якості звітності } \\
\text { та обгрунтованості використаних } \\
\text { процедур аудиту }\end{array}$ & $\begin{array}{lcc}\text { Ідентифікація } & \text { ключових } & \text { інтересів } \\
\text { стейкхолдерів, } & \text { найбільш } & \text { суттєвих } \\
\text { сфер ЗСР } & & \end{array}$ \\
\hline Верифікатори & $\begin{array}{l}\text { Зовнішні аудитори, професійні } \\
\text { аудиторські компанії та мережі }\end{array}$ & $\begin{array}{lr}\text { Спеціальні } & \text { органи, здебільшого } \\
\text { уповноважені } \\
\text { компаній }\end{array}$ \\
\hline $\begin{array}{l}\text { Принцип } \\
\text { побудови }\end{array}$ & $\begin{array}{l}\text { Базується на професійному } \\
\text { судженні }\end{array}$ & $\begin{array}{l}\text { Базується на етичних принципах i } \\
\text { детальних процедурах }\end{array}$ \\
\hline Думка аудитора & Аудиторський висновок & Звіт визначеної форми \\
\hline $\begin{array}{l}\text { Рівень } \\
\text { впевненості }\end{array}$ & Обгрунтована, обмежена & Низький, середній або високий \\
\hline $\begin{array}{l}\text { Основний } \\
\text { компонент }\end{array}$ & Бухгалтерська практика & $\begin{array}{l}\text { Процес «Підзвітність за сталий } \\
\text { розвиток» }\end{array}$ \\
\hline $\begin{array}{l}\text { Тема } \\
\text { обговорення }\end{array}$ & $\begin{array}{l}\text { Дає вказівки щодо «розуміння } \\
\text { теми» }\end{array}$ & $\begin{array}{l}\text { Стосується звітів і систем, процесів і } \\
\text { компетенцій }\end{array}$ \\
\hline $\begin{array}{l}\text { Етичні вимоги } \\
\text { та контроль } \\
\text { якості }\end{array}$ & $\begin{array}{l}\text { - виступає за контроль якості та } \\
\text { посилається на детальні вказівки } \\
\text { - включає кодекс, що охоплює } \\
\text { основні етичні вимоги }\end{array}$ & $\begin{array}{l}\text { - не перелічує вимог, хоча Стандарт } \\
\text { виступає за те, щоб аудитор був } \\
\text { готовий розкривати незалежність, } \\
\text { неупередженість і компетентність } \\
\text { - конкретно не посилається на } \\
\text { контроль якості, хоча розроблений } \\
\text { так, щоб він відповідав іншим } \\
\text { пов'язаним стандартам }\end{array}$ \\
\hline $\begin{array}{l}\text { Планування та } \\
\text { виконання } \\
\text { зобов'язання }\end{array}$ & $\begin{array}{lr}\text { Надає рекомендації } & \text { щодо } \\
\text { планування } & \text { подальшої } \\
\text { економічної } & \text { діяльності } \\
\text { організації } & \end{array}$ & $\begin{array}{l}\text { Не стосується конкретно планування } \\
\text { та виконання зобов'язань із надання } \\
\text { впевненості, хоча Стандарт } \\
\text { розроблений так, щоб він відповідав } \\
\text { iншим пов'язаним стандартам і } \\
\begin{array}{l}\text { посилається на } \\
\text { узгодження рівня впеохідність } \\
\text { критеріїв виконання зобов'язань }\end{array}\end{array}$ \\
\hline
\end{tabular}




\begin{tabular}{|c|c|c|}
\hline & & $\Pi p$ \\
\hline Суттєвість & 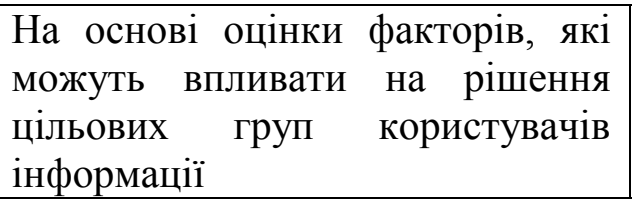 & $\begin{array}{l}\text { На основі оцінки того, чи достатньо } \\
\text { інформації для того, щоб зацікавлені } \\
\text { сторони } \\
\text { обгрунтовані судження }\end{array}$ \\
\hline Обсяг & Заздалегідь визначений & $\begin{array}{l}\text { Визначається, ураховуючи фінансові } \\
\text { міркування, регламенти та } \\
\text { стандарти, організаційну політику, } \\
\text { та поведінку зацікавлених сторін }\end{array}$ \\
\hline Критерії & $\begin{array}{l}\text { Аудитор використовує міркуван- } \\
\text { ня щодо суттєвості під час } \\
\text { оцінки відповідності повідом- } \\
\text { леної інформації критеріям }\end{array}$ & $\begin{array}{l}\text { Аудитор оцінює якість взаємодії } \\
\text { організації із стейкхолдерами та } \\
\text { надійність процесів прийняття } \\
\text { рішень і критерії звітності }\end{array}$ \\
\hline $\begin{array}{l}\text { Повнота та } \\
\text { достовірність }\end{array}$ & $\begin{array}{l}\text { Забезпечує впевненість у повноті } \\
\text { та достовірності повідомленої } \\
\text { інформації стосовно критеріїв } \\
\text { звітності лише у вказаний період } \\
\text { часу }\end{array}$ & 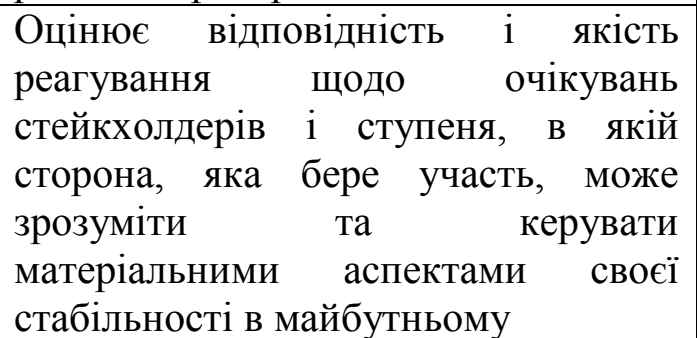 \\
\hline нна заява / & $\begin{array}{lrr}\text { Дає } & \text { висновок } & \text { розумною } \\
\text { впевненістю (позитивна форма) } \\
\text { або обмеженою } \quad \text { впевненістю } \\
\text { (негативна форма) щодо того, чи } \\
\epsilon \text { аналіз надійним і справедливим } \\
\end{array}$ & $\begin{array}{l}\text { Публічна заява / звіт дає вичерпний } \\
\text { опис результатів щодо якості звіту, } \\
\text { що лежать в основі систем } \\
\text { управління / процесів і підзвітності }\end{array}$ \\
\hline $\begin{array}{l}\text { Незалежність і } \\
\text { неупередженість }\end{array}$ & 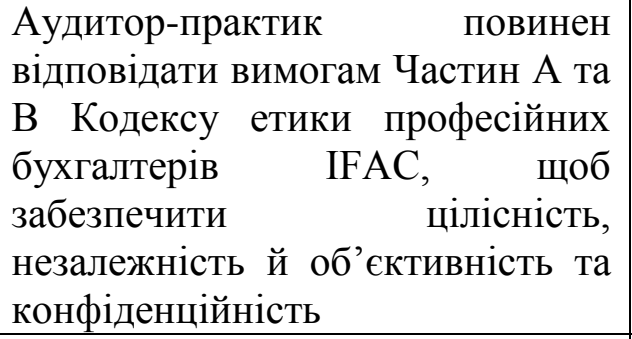 & $\begin{array}{l}\text { Аудитор повинен оприлюднити } \\
\text { iнформацію про його незалежність } \\
\text { від Організації звітування та } \\
\text { неупередженість щодо зацікавлених } \\
\text { сторін }\end{array}$ \\
\hline Комп & $\begin{array}{l}\text { Аудитор повинен забезпечити, } \\
\text { щоб команда, яка займається } \\
\text { роботою, володіла необхідними } \\
\text { професійними компетентностями } \\
\text { (включаючи } \\
\text { спеціальні знання та вміння) для } \\
\text { оцінки предмета дослідження }\end{array}$ & $\begin{array}{l}\text { Аудитор зобов’язаний оприлюднити } \\
\text { інформацію про власні компетенції - } \\
\text { це є частиною заяви / звіту. }\end{array}$ \\
\hline Право & $\begin{array}{l}\text { Дозволяється лише один підпис, } \\
\text { проте персоналізований }\end{array}$ & $\begin{array}{l}\text { итання підпису в Стандарті } \\
\text { ено }\end{array}$ \\
\hline
\end{tabular}

Джерело: розроблено авторами на основі [22].

Відтак, необхідно зазначити, що ISAE 3000 та AA1000AS $є$ двома основними стандарти із надання впевненості, які застосовують суттєво різні підходи. ISAE 3000 використовується аудиторськими компаніями та наголошує на якості даних та процедурах збору доказів. AA1000AS використовується спеціалізованими компаніями з підтвердженням та наголошує на необхідності організації демонструвати ефективну взаємодію зацікавлених сторін, визначати 


\section{Agricultural and Resource Economics}

www.are-journal.com

питання сталого розвитку та створювати відповідальну бізнес-стратегію для відповіді на ці актуальні проблеми.

Цінність AA1000AS полягає в тому, що він був розроблений фахівцями 3 питань сталого розвитку у відповідь на занепокоєння зацікавлених сторін щодо вузького фокусу стандарту ISAE 3000 та обмеженої ефективності заяв про достовірність, які написані без вагомих висновків і рекомендацій, що випливають із процесу впевненості.

Разом із тим, незважаючи на наявність принципових відмінностей у використанні та поширенні (зі значним відривом частка AA1000AS серед спеціалізованих провайдерів упевненості й технічних експертів становить 76,5 \% на противагу 11,8 \% ISAE 3000) зазначені стандарти доступні й навіть рекомендовані для спільного використання. ISAE 3000 найбільш часто використовується найбільшими аудиторськими фірмами та мережами [22].

При цьому частка їх спільного використання дорівнює частоті використання ISAE 3000 для підтвердження ЗСР серед 100 випадково відібраних компаній із баз CorporateRegister.com та Sustainability Disclosure Database Глобальної ініціативи зі звітності (Global Reporting Initiative, рис. 3).

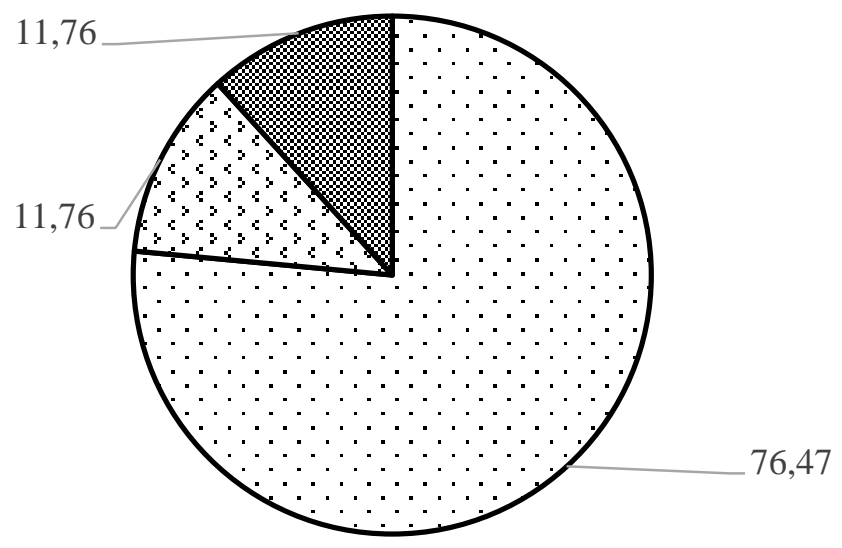

\section{ㅁA 1000 AS ISAE 3000 AA 1000 AS \& ISAE 3000}

Рис. 3. Стандартизація аудиту звітності зі сталого розвитку

Джерело: розроблено авторами на основі [23].

Основна відмінність ISAE 3000 від AA1000AS полягає в тому, що перший фокусується на процедурах надання впевненості щодо ЗСР, а другий - на якості процесів звітності. AA1000AS може бути використаний організацією, що звітує, для визначення обсягу звітності та предмета інформації, що підлягає розкриттю, тоді як ISAE 3000 може використовуватися провайдером підтвердження, щоб визначити умови надання зобов'язань, планувати та виконувати завдання, а також отримати необхідні докази та витримати етичні вимоги [23]. На заключних етапах аудиторська фірма може використовувати AA1000AS для надання висновку про принципи суттєвості, повноти та дотримання концептуальної основи у звітності. 


\section{Agricultural and Resource Economics}

www.are-journal.com

Висновки. Активізація компаній у публікації ЗСР потребує напрацювання виважених підходів до іiі підтвердження аудиторами, а відтак - уніфікації підходів до їх стандартизації. Базовими стандартами, що визначають порядок аудиту 3СР, є AA1000 AS та ISAE 3000. Результати компаративного аналізу зазначених стандартів дозволяють визнати, що AA1000 AS має потенційні вигоди на противагу ISAE 3000, оскільки:

- забезпечує цілісний стандарт для оцінки того, що соціальні рахунки / звіти організації систематично стосуються відповідного діапазону ефективності та соціального, екологічного й економічного впливу;

- прагне прищепити культуру постійного розвитку за допомогою реакції зацікавлених сторін;

- підтримує та інтегрує інші інструменти, такі як Керівні принципи глобальної звітності, SA8000, SIGMA та серія ISO;

- надає вказівки щодо якості інформації про результативність сталого розвитку, розкритої суб'єктом господарювання, та допомагає узгоджувати нефінансові аспекти сталості із фінансовими показниками.

Проте поряд із перевагами визначено й потенційні обмеження:

- використання стандарту AA1000 AS може також бути обмеженням, якщо організація проходить роботу з планування, обліку, аудиту та звітності без істотного покращення іiі ефективності та впливу, на відміну від ISAE 3000;

- AA1000 AS дає гарантію якості процесів підзвітності організації, але не забезпечує підвищення інвестиційної привабливості;

- на відміну від ISAE 3000, AA1000 AS є більш трудомістким для деяких підприємств і може бути незрозумілим.

3 урахуванням вигід та обмежень проаналізованих стандартів на регуляторному рівні, зокрема й в Україні, можуть бути розроблені національні підходи щодо стандартизації аудиту ЗСР. На рівні окремих компаній зазначені стандарти можуть використовуватися паралельно в комунікативному полі їх взаємодії зі стейкхолдерами залежно від категорій зазначених сторін.

Подяка. Матеріал підготовлено в рамках НДР «Корпоративна соціальноекологічна відповідальність для сталого розвитку: партнерство стейкхолдерів реального, фінансового та державного секторів економіки» № державної реєстрації 0117 U003933.

\section{Список використаних джерел}

1. Голубева Н. А. Аудит: система верификации корпоративной социальной отчетности: автореф. дис. ... канд. экон. наук. Москва, 2012. 30 с.

2. Баришнікова О. М. Особливості організації системи верифікації звітності сталого розвитку. Економіка та держава. 2016. № 8. С. 131-140.

3. Мазурик О. В. Соціальний аудит як сучасна діагностична технологія: теоретико-методологічні засади дослідження, західний досвід, вітчизняні перспективи. Вісник Харківського начіонального університету імені В.Н. Каразіна. Серія: Сочіологічні дослідження сучасного суспільства: методологія, теорія, методи. 2015. № 1148. Вип. 34. С. 107-113. 
4. Waddock S., Smith N. Corporate Responsibility Audits: Doing Well by Doing Good. Sloan Management Review. 2000. Vol. 41. Is. 2. Pp. 75-83.

5. Gray R. Current developments and trends in social and environmental auditing, reporting and attestation: a review and comment. International Journal of Auditing. Vol. 4. Is. 3. Pp. 247-268. https://doi.org/10.1111/1099-1123.00316.

6. Каптерев А. И. Англосаксонская модель социального аудита Глобальные экономические, социальные и информационные проблемы современности. URL: http://www.globecsi.ru/Articles/2007/Anglosaks.pdf.

7. Карагод В. С. Реалии аудиторского контроля социальной ответственности российского бизнеса. Вестник Московской государственной академии делового администрирования. 2012. № 2. С. 103-110.

8. Kok P., van der Wiele, T., McKenna R., Brown A. A Corporate social responsibility audit within a quality management framework. Journal of Business Ethics. 2001. No. 31. Pp. 285-297.

9. Morimoto R., Ash J., Hope C. Corporate social responsibility audit: from theory to practice. Journal of Business Ethics. 2005. Vol. 62. Pp. 315-325. https://doi.org/10.1007/s10551-005-0274-5.

10. Boiral O., Heras-Saizarbitoria I., Brotherton M. Assessing and improving the quality of sustainability reports: the auditors' perspective. Journal of Business Ethics. 2019. Vol. 155. Pp. 703-721. https://doi.org/10.1007/s10551-017-3516-4.

11. Al- Shaer H., Zaman M. Credibility of sustainability reports: the contribution of audit committees. Business Strategy and the Environment. 2018. Vol. 27. Is. 7. Pp. 973- 986. https://doi.org/10.1002/bse.2046.

12. Al-Shaer H., Zaman M. CEO compensation and sustainability reporting assurance: evidence from the UK. Journal of Business Ethics. 2019. Vol. 158. Pp. 233-252. https://doi.org/10.1007/s10551-017-3735-8.

13. Michelon G., Patten D. M., Romi A. N. Creating legitimacy for sustainability assurance practices: evidence from sustainability restatements. European Accounting Review. 2019. Vol. 28. Is. 2. Pp. 395-422. https://doi.org/10.1080/09638180.2018.1469424.

14. Kaya I. Sustainability reporting assurance: a literature survey. Regional Studies on Economic Growth, Financial Economics and Management. Eurasian Studies in Business and Economics. M. Bilgin, H. Danis, E. Demir, U. Can eds. Vol. 7. Cham: Springer, 2017. Pp. 33-50. https://doi.org/10.1007/978-3-319-541129_3.

15. Vasilieva T., Lieonov S., Makarenko I., Sirkovska N. Sustainability information disclosure as an instrument of marketing communication with stakeholders: markets, social and economic aspects. Marketing and management of innovation. 2017. No. 4. Pp. 350-357. http://doi.org/10.21272/mmi.2017.4-31.

16. Corporate register. URL: https://www.corporateregister.com/livecharts.

17. KPMG. The KPMG Survey of Corporate Responsibility Reporting. URL: https://assets.kpmg/content/dam/kpmg/be/pdf/2017/kpmg-survey-of-corporateresponsibility-reporting-2017.pdf. 


\section{Agricultural and Resource Economics}

www.are-journal.com

18. International standard on assuarance engagements (ISAE) 3000. URL: https://www.ifac.org/system/files/downloads/b012-2010-iaasb-handbook-isae3000.pdf.

19. Exposure draft [proposed] international standard on assuarance engagements 3000 - Assurance Engagements other than Audits or Reviews of Historical Financial Information. URL: https://www.frc.org.uk/getattachment/311785cc-40dd-412b-97b750ecc76f83b3/ISAE-3000-Exposure-Draft-March-2020.pdf.

20. AA1000 AccountAbility Principles Standard. URL: http://www.accountability.org/about-us/publications/aa1000.html.

21. Guidance for AA1000AS. Assurance Providers. URL: http://www.masbusiness.com/docs/Guidance\%20for\%20AA1000AS\%202008\%20Assurance\%20Pro viders.pdf.

22. Assurance Standards Briefing. AA1000 Assurance Standard \& ISAE3000. KPMG, Netherlands. URL: https://www.accountability.org/wpcontent/uploads/2016/11/Assurance-Standards-Briefing.pdf.

23. Current state of assurance on sustainability reports. URL: https://www.cpajournal.com/2017/07/26/current-state-assurance-sustainabilityreports.

\section{References}

1. Golubeva, N. A. (2012), Audit: system of verification of CSR reporting, Ph.D. Thesis, RUDN University, Moskow, Russia.

2. Baryshnikova, O. Features of verification of sustainable development report. Ekonomika ta derzhava, no. 8, pp. 131-140.

3. Mazuryk, O. V. (2015), Social audit as a modern diagnostic technology: theoretical and methodological principles of research, Western experience, domestic prospects. Visnyk V. N. Karazin Kharkiv National University. Series «Sociological studies of contemporary society: methodology, theory, methods», no. 1148, 1vol. 34, pp. 107-113.

4. Waddock, S. and Smith, N. (2000), Corporate responsibility audits: doing well by doing good. Sloan Management Review, vol. 41, is. 2, pp. 75-83.

5. Gray, R. (2000), Current developments and trends in social and environmental auditing, reporting and attestation: a review and comment. International Journal of Auditing, vol. 4, is. 3, pp. 247-268. https://doi.org/10.1111/1099-1123.00316.

6. Kapterev, A. (2007), Anglo-Saxon model of social audit global economic, social and information problems of the present, available at: http://www.globecsi.ru/Articles/2007/Anglosaks.pdf.

7. Karagod, V. (2012), The realities of audit control of social responsibility of Russian business. Bulletin of the Moscow State Academy of Business Administration, no. 2, pp. 103-110.

8. Kok, P., van der Wiele, T., McKenna, R. and Brown, A. (2001), A corporate social responsibility audit within a quality management framework. Journal of 
Business Ethics, no. 31, pp. 285-297.

9. Morimoto, R., Ash, J., Hope, C. (2005), Corporate social responsibility audit: from theory to practice. Journal of Business Ethics, vol. 62, pp. 315-325. https://doi.org/10.1007/s10551-005-0274-5.

10. Boiral, O., Heras-Saizarbitoria, I. and Brotherton, M. (2019) Assessing and improving the quality of sustainability reports: the auditors' perspective. Journal of Business Ethics, vol. 155, pp. 703-721. https://doi.org/10.1007/s10551-017-3516-4.

11. Al- Shaer, H., Zaman, M. (2018), Credibility of sustainability reports: the contribution of audit committees. Business Strategy and the Environment, vol. 27, is. 7, pp. 973- 986. https://doi.org/10.1002/bse.2046.

12. Al-Shaer, H. and Zaman, M. (2019), CEO compensation and sustainability reporting assurance: evidence from the UK. Journal of Business Ethics, vol. 158, pp. 233-252. https://doi.org/10.1007/s10551-017-3735-8.

13. Michelon, G., Patten, D. M. and Romi, A. N. (2019), Creating legitimacy for sustainability assurance practices: evidence from sustainability restatements. European Accounting Review, vol. 28, is. 2, pp. 395-422. https://doi.org/10.1080/09638180.2018.1469424.

14. Kaya, I. (2017), Sustainability reporting assurance: a literature survey. in Regional Studies on Economic Growth, Financial Economics and Management. Eurasian Studies in Business and Economics, eds. M. Bilgin, H. Danis, E. Demir, U. Can, vol. 7. Cham, Springer, Switzerland. https://doi.org/10.1007/978-3-31954112-9_3.

15. Vasilieva, T., Lieonov, S., Makarenko, I. and Sirkovska, N. (2017), Sustainability information disclosure as an instrument of marketing communication with stakeholders: markets, social and economic aspects. Marketing and management of innovation, no. 4, pp. 350-357. http://doi.org/10.21272/mmi.2017.4-31.

16. Corporate register, available at: https://www.corporateregister.com/livecharts.

17. KPMG (2017), The KPMG Survey of corporate responsibility reporting, available at: https://assets.kpmg/content/dam/kpmg/be/pdf/2017/kpmg-survey-ofcorporate-responsibility-reporting-2017.pdf.

18. International standard on assuarance engagements (ISAE) 3000, available at: https://www.ifac.org/system/files/downloads/b012-2010-iaasb-handbook-isae3000.pdf

19. Exposure draft [proposed] international standard on assuarance engagements 3000 - Assurance Engagements other than Audits or Reviews of Historical Financial Information, (2020), available at: https://www.frc.org.uk/getattachment/311785cc40dd-412b-97b7-50ecc76f83b3/ISAE-3000-Exposure-Draft-March-2020.pdf

20. AA1000 AccountAbility Principles Standard (2019), available at: http://www.accountability.org/about-us/publications/aa1000.html.

21. Guidance for AA1000AS (2008), Assurance Providers, available at: http://www.mas-business.com/docs/Guidance\%20for\%20AA1000AS\%202008\%20 Assurance\%20Providers.pdf. 
22. Assurance Standards Briefing (2005), AA1000 Assurance Standard \& ISAE3000. KPMG, Netherlands, available at: https://www.accountability.org/wpcontent/uploads/2016/11/Assurance-Standards-Briefing.pdf.

23. Current state of assurance on sustainability reports (2017), URL: https://www.cpajournal.com/2017/07/26/current-state-assurance-sustainabilityreports.

How to cite this article? Як цитувати цю статтю?

Стиль - ДСТУ:

Макаренко I., Кравченко О., Овчарова Н., Земляк Н., Макаренко С. Стандартизація аудиту звітності зі сталого розвитку компаній. Agricultural and Resource Economics. 2020. Vol. 6. No. 2. Pp. 78-90. URL: http://are-journal.com.

Style-Harvard:

Makarenko, I., Kravchenko, O., Ovcharova, N., Zemliak, N. and Makarenko, S. (2020), Standardization of companies' sustainability reporting audit. Agricultural and Resource Economics, vol. 6, no. 2, pp. 78-90. URL: http://are-journal.com. 